\title{
THE EFFECTS OF DEMOGRAPHICAL FACTORS AND BRAND ASSOCIATIONS ON SATISFACTION: UNIVERSITY SAMPLE*
}

\author{
Research Asist., Gizem TOKMAK \\ Bülent Ecevit University, Faculty of Economics and Administrative Sciences, (gizem.tokmak@beun.edu.tr)
}

\begin{abstract}
This study aims to reveal the effects of demographical factors and brand associations on university satisfaction of the students thought to be the most effective internal customer groups in conveying university image. The population comprises of 1922 students including freshmen and seniors studying at the faculty of economics and business administration of the subject university. In the research, 389 participants were reached via quota sampling method, and multiple linear regression analysis was applied. In conclusion, the brand associations including academicians characteristics, physical features, intangible factors including benefits and university image were found to be effective variables on university satisfaction.
\end{abstract}

Keywords: Brand Associations, Satisfaction, Word of Mouth (WOM), University Image.

\section{DEMOGRAFIK FAKTÖRLERIN VE MARKA ÇAĞRIŞIM UNSURLARININ MEMNUNIYET ÜZERINDEKİ ETKISII: ÜNIVERSITE ÖRNEĞİ}

\begin{abstract}
ÖZET
Bu çalışmada demografik faktörlerin ve marka çă̆rışım unsurlarının, üniversite imajını iletmede en etkili iç müşteri grubu olduğu düşünülen ögrrencilerin üniversite memnuniyeti üzerindeki etkilerini ortaya çıkarmak amaçlanmıştır. Ana kütleyi, söz konusu üniversitenin I.İ.B.F.'nde dördüncü ve birinci sınıfta okumakta olan 1922 ögrenci oluşturmaktadır. Araştırmada kota örnekleme yöntemiyle 389 katılımcı belirlenmiş ve çoklu doğrusal regresyon tekniğ i kullanılmıştır. Sonuç olarak, akademisyenlerin özellikleri ve fiziksel özellikler gibi marka çă̆rışım unsurları ile fayda ve üniversite imajı gibi soyut faktörler, üniversite memnuniyeti üzerinde etkili de ğişkenler olarak bulunmuştur.
\end{abstract}

Anahtar Kelimeler: Marka Çă̆rışım Unsurları, Memnuniyet, WOM, Üniversite İmajı.

\footnotetext{
* This paper was presented at "International Conference on Social Science and Education Research" on 28-31 October 2015, Antalya.
} 


\section{Introduction}

The importance of brand concept increases day by day with the globalisation and technological development which remove the borders between the countries and cultures. As the borders become removed, the similarities between the products to be marketed increase. In these similarities' world, the brands should differentiate from each other to survive and get competitive advantage (Hunt, 2010).

Aaker (1996) suggests that brands should focus on brand equity elements in order to create differences among the rival brands. Brand equity elements including brand loyalty, perceived quality, brand associations and brand awareness are the intangible factors for the brands to create differentiation. In today's marketing world where customer based point of view exists, it becomes fundamental for brands to focus on intangible factors which will constitute brand loyalty and psychological commitment towards customers (Koç, 2012).

Branding process is fundamental not only for the tangible products, but also for the institutions. Especially for the institutions which perform in service sectors including education, logistic, and entertainment, it becomes crucial to focus on the brand equity elements while developing marketing strategies to achieve differentiation and satisfaction factors towards the customers.

The institutions performed in service sector should constitute satisfaction factor for both their internal customers and their external customers as satisfaction factor brings positive word of mouth creating a strong brand image and awareness for the mentioned institutions (İslamoğlu \& Altunış1k, 2013). When educational institutions such as the universities are considered; the existing students, the academical staffs and managerial staffs become the internal customers of the university. On the other hand, the macro environmental issues such as the potential students who will make a university preference, the public, and the potential investors become the external customers of the university. It becomes important for an educational institution to create satisfaction on both its internal and external customers which may bring positive word of mouth creating strong brand image. So, to investigate the existing satisfaction level of the students and/or university preference reasons may guide the institution to develop its current condition.

It is seen that there are several university preference reasons of the students in Turkey. For instance; Owen et al. (2011) revealed that personal, systematical, social and chance factors were effective on the Turkish students department preference. In addion, Akar (2012) investigated the factors affecting university preferences of the f.e.a.s. students studying in the universities in South Marmara region of Turkey, and revealed that the factors including academic prestige, geographical position of the university, and the sources giving information about the university were effective on the students' university preference. Besides, income status of the students, geographical region and residences places were found to be effective variables on university preferences of the students. On the other hand, Tekelioğlu et al. (2012) investigated the factors affecting university and country preferences of the international students and revealed that education quality, scholarship opportunity and scientific success were highly effective variables on university preference. However, they revealed that the factors including 
friend recommendation and social opportunities were not found to be as effective as the other variables on university preference.

University satisfaction of the students is also as important as university preference reasons of the students to evaluate the current position of a university and to take precaution that is needed. It is also seen that there are several factors creating university satisfaction for Turkish students. For instance; Şahin (2009) investigated the satisfaction of the students studying in the department of primary education teaching in Hacettepe University towards education service and revealed that the satisfaction level of the students in management, sources and computer opportunities dimensions was quite low; on the other hand, the students were satisfied from the academic staffs, consultancy and schedules dimensions in moderate level. Sökmen (2011) investigated student satisfaction in a vocational school in Ankara, and revealed that gender and program groups of the students created significant differences on satisfaction. Şahin et al. (2011) revealed that career preparation of the university were the primary function that the students expected from the university. Baltac1 et al. (2013) investigated the satisfaction of students studying on tourism in Turkey, and revealed that the students uncounciously preferred the department of tourism. In addition, they revealed that the upper level students were more worried about the future and dissatisfied with education. Besides, Yangin and Kirca (2013) investigated the satisfaction level of nursing students and factors affecting satisfaction, and revealed that the quality of the education and academic staffs were the most effective variables creating satisfaction. In addition, they revealed that the freshmen were the most satisfied students group among the students, and the students' feelings towards the department and the attendance to the social-scientific activities and students clubs affected satisfaction level of the students.

In this research, it was aimed to find out the brand association factors affecting university satisfaction of the students thought to be the most effective internal customers group of the university for developing a positive word of mouth (WOM) for the university. By basing on the statement suggested by Aaker (1996) indicating that brand association factors are the precessors of the other brand equity elements, the association elements were investigated for this research. Besides, the number of researches measuring the effects of demographical factors on satisfaction and institutional brand image is very restricted in the literature guiding the researcher to study on the mentioned variables. Thus, to reveal the effects of demographical factors on university satisfaction is expected to be a contribution to the literature.

\section{Literatur Review and Hypotheses}

\subsection{Brand Associations}

Brand associations are shaped by and consist of the concepts of brand identity, brand personality and brand image (Aaker, 1996). The concepts constituting brand associations should be explicitly diversified in order to develop an effective branding strategy.

\subsubsection{Brand Image}

Brand image is a concept about how a customer perceives a brand (Aaker, 1996:85). The perception of the customer towards the brand occurs and shapes as he/she experiences 
the brand over time. The experiences received by the customer from the brand comprise of the controllable features of the brand such as weaknesses and strenghts of the brand (Perry \& Wisnom, 2003:15). The other factors constituting brand image comprise of the factors related to product and factors unrelated to product of the brand, in other words tangible and intangible features of the brand such as brand awareness, brand name, brand logo, brand packaging and customer relationship process (Perry \& Wisnom, 2003:15-16). The mentioned features constituting brand image and experiences perceived guide the customers in the process of brand preference and purchasing.

In today's marketing world, not only the branding process of tangible and intangible products, but also the branding process of the institutions became crucial revealing the concept of corporate brand image.

\subsubsection{Corporate Image}

Corporate image means instant impressions of people about a corporation (Stuart, 1999). To constitute a corporate image, it is not necessary to have an information or an experience about the corporation. The word of mouth communication plays an important role in the formation of corporate image. Grönroos (1988) states that the technical and functional quality of the services performed by the corporation is very effective in the process of brand image formation.

Corporate image is shaped by the impressions of the target customers about the corporation (Dinçer, 2001). Corporate image is very effective to constitute customer satisfaction and loyalty in the way of affecting the perceived quality of the customers (Andreassen \& Lindestad, 1998).

\subsubsection{Dimensions of Corporate Image}

Factors constituting corporate image and the dimensions of corporate image have been investigated and classified by several researchers in the literature. The generally accepted classification study about corporate image belongs to the studies performed by Keller in 2000 and in 2003.

Table 1: Factors Constituting Corporate Image and Corporate Image Dimensions

\begin{tabular}{|c|c|}
\hline \multicolumn{2}{|c|}{ Factors Constituting Corporate Image } \\
\hline Factor & Content \\
\hline The Corporation Itself & $\begin{array}{l}\text { Reputation, innovativeness, financial power, } \\
\text { industry position, management quality etc. }\end{array}$ \\
\hline Social Environment of the Corporation & The Society, country, quality of living etc. \\
\hline Corporate Staffs & Prestige, salary, promotion condition etc. \\
\hline Assistances of the Corporation & $\begin{array}{c}\text { Charities, schools, organisations of art, sport } \\
\text { clubs etc. }\end{array}$ \\
\hline Sale Force of the Corporation & $\begin{array}{l}\text { Size, coverage zone, reliability, } \\
\text { responsibilities, courtesy etc. }\end{array}$ \\
\hline
\end{tabular}


Table 1 continued

\begin{tabular}{cc}
\hline Products of the Corporation & Quality, performance, style etc. \\
\hline Corporate Image Dimensions \\
\hline Human Relations Dimension & $\begin{array}{c}\text { Quality, degree of innovation, product level } \\
\text { (core product, tangible product, extended } \\
\text { product) }\end{array}$ \\
\hline Corporate Reliability & $\begin{array}{c}\text { Structure of the internal and external customer } \\
\text { groups of the firm, the relations with these } \\
\text { customers }\end{array}$ \\
\hline
\end{tabular}

Resource: Keller, K. L. (2000). Conceptualizing, measuring, and managing customer based brand equity. Journal of Marketing, 1(57), 1-22; Keller, K. L. (2003). Strategic brand management, building, measuring and managing brand equity. New Jersey: Prentice Hall.

Table 1 indicates the factors constituting corporate image and the corporate image dimensions. The corporations should be aware of these factors in the process of an effective marketing strategy development in order to attract internal and external customers.

\subsection{Brand Association Factors}

Keller (2000:5) states that brand association factors consist of the factors related to product, factors unrelated to product, benefits and attidues of a brand.

\subsubsection{Brand Benefits}

The benefits thought to have effect on university satisfaction of the students comprise of the intangible factors such as acceptance to the group, escape, socialisation, sensitive satisfaction, amusement and nostalgia. The sum of these intangible factors constitutes the perceived quality. The perceived quality are divided into three categories which are functional, experimental and symbolic. The functional benefits are related to the internal features of the product and especially satisfy physical and security needs of the consumers. The experimental benefits are mostly related to the factors unrelated to product and satisfy the experimental needs including amusement and diversity. The symbolic benefits are related to the factors unrelated to product just as the experimental benefits, but they are also related to the motives of the consumers such as self-expression, social acceptance, and self trust (Keller, 2000:4).

The benefits provided by the university to the students who are the internal customers of the university consist of the intangible factors such as socialisation, point of view development, and making them vision holders. Wilkins \& Huisman (2014), Torlak et al. (2014), Jiewanto et al. (2014), and Akareem \& Hossain (2012) state that the intangible factors provided by the brand increase brand satisfaction of the customers, and the students become more satisfied from the university as the university provides socialisation facilities for students. In that vein, the below hypothesis was established for the research: 
H1: The benefits provided by the university have statistically meaningful effect on university satisfaction of the students.

\subsubsection{Factors Related to Product}

Keller (2000) states that the factors related to product is very essential so that the product can actualise the performance expected by the customers. The factors related to product contribute to the product performance and meet the expectations of the customers from the product. When the university is considered as a marketing product, the factors related to product of the university include the academicians characteristics such as availability and proficiency of the academician, capability of communication, guidance, helpfullness, and the courses characteristics. The researches performed by Wilkins \& Huisman (2014), Akareem \& Hossain (2012), Pavlina et al. (2011), Özgüngör (2009) and Yeygel \& Temel (2006) indicate that the characteristics of academicians and courses are effective on university satisfaction of the students. In that vein the below hypothesis was established for the research:

$\mathrm{H} 2$ : Factors related to product of the university have statistically meaningful effect on university satisfaction of the students.

\subsubsection{Factors Unrelated to Product}

Keller (2000) states that factors unrelated to product do not have any effects on the produt performance but do have effect on the sale and consumption of the product. When the university is considered as a marketing product, the factors unrelated to product include the physical features of the university such as logo or slogan of the university, campus characteristics, constructions and facilities of the university. Alwi \& Kitchen (2014), Wilkins \& Huisman (2014), Akareem \& Hossain (2012), and Yeygel \& Temel (2006) indicate that the factors unrelated to product such as physical conditions of the university have an effect on university satisfaction of the students. In that vein, the below hypothesis was established for the research:

H3: Factors unrelated to product of the university have statistically meaningful effect on university satisfaction of the students.

In the literature, the number of researches measuring the possible effect of demographical factors on brand image and satisfaction is limited. Chen (2008) revealed that demographical factors such as gender, place of living and year of study had effects on the perceived university brand image of the students. This conclusion became a trigger point for developing the below hypotheses for the research.

H4a: Gender has a statistically meaningful effect on university satisfaction of the students.

H4b: Year of study has a statistically meaningful effect on university satisfaction of the students. 
H4c: Place of living has a statistically meaningful effect on university satisfaction of the students.

H4d: The reason of university preference has a statistically meaningful effect on university satisfacion of the students.

\section{Methodology}

\subsection{Research Design and Data Collection Process}

The population of the research consists of 920 freshmen and 1002 seniors studying at the faculty of economics and business administration of the subject university. Quota sampling method was performed for the research. To avoid from the error which could be caused by quota sampling method, two layers including gender and year of study were determined, and the elements were picked according to their ratio in the population. For the research 389 participants were reached. The distribution of the participants according to the layers are indicated in Table 2:

Table 2: Number of Students According to Year of Study and Gender-Sample Size

\begin{tabular}{cccc}
\hline Year of Study & Girl & Boy & The Sum \\
\hline 1st Year & 104 & 82 & 186 \\
\hline 4th Year & 115 & 88 & 203 \\
\hline The Sum & $\mathbf{2 1 9}$ & $\mathbf{1 7 0}$ & $\mathbf{3 8 9}$ \\
\hline
\end{tabular}

\subsection{Measurement Tool}

Questionaire technique was applied for the research. The questionaire form consists of six sections. In the first section, "academicians' characteristics" were evaluated and the statements about the academicians' characteristics were attained and adapted from the researches performed by the researchers including Alwi \& Kitchen (2014), Akareem \& Hossain (2012), Pavlina et al. (2011) and Özgüngör (2009). In the second, third, fouth and fifth sections, there are the statements measuring the existing attitudes of the participants about "the physical characteristics of the university", "course characteristics", "the institutional characteristics of the university", "the perceived quality of the university" and "the satisfaction from the university". The mentioned statements were attained and adapted from the researches performed by the researchers including Yeygel \& Temel (2006), Tiğlı (2003), Marangoz \& Biber (2007), Parpala \& Ylanne (2007), Jiewanto et al. (2012) and Wilkins \& Huisman (2014). The statements were evaluated by using five point Likert Scale. In the sixth section of the questionaire, the demographical variables of the participants were evaluated. 
Figure 1: Model of the Research

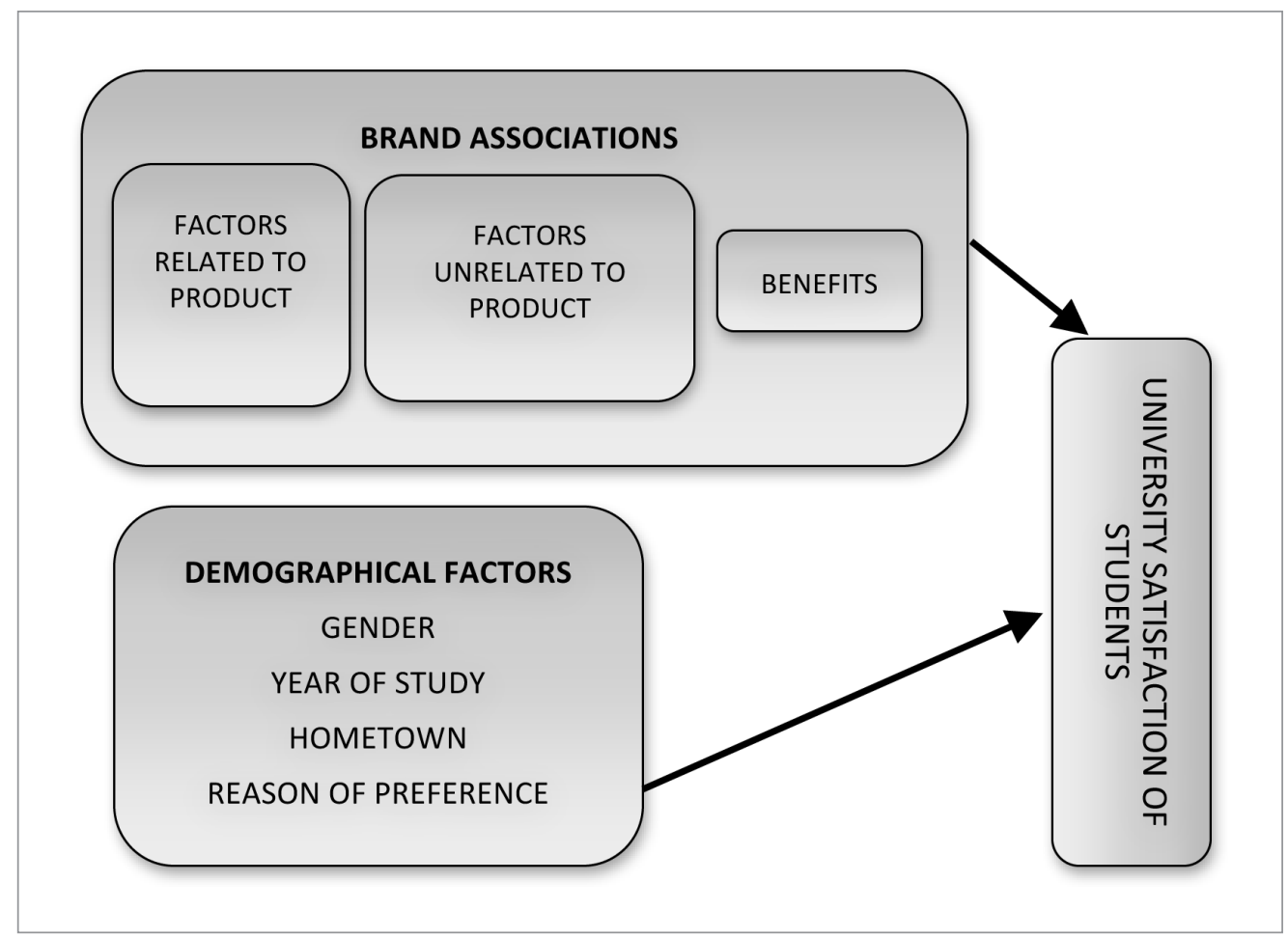

\subsection{Analysis Process}

Firstly, Cronbach's Alpha Reliability Model was performed to test the scales' reliabilities. The scales' reliability coefficients ${ }^{1}$ were found within the range of $0,70-1,000$ indicating that the scales had high reliability scores. After the reliability analyses had been performed, the exploratory factor analyses ${ }^{2}$ were applied. From the scale measuring the characteristics of the academicians, 4 factors were obtained $(\mathrm{KMO}=0.852$; $\mathrm{Sig}=0.000)$. From the scale measuring the physicalconditions of the university, 4 factors were obtained $(\mathrm{KMO}=0.657$; Sig. $=0.000)$. From the scale measuring the institutional characteristics of the university, 3 factors were obtained $(\mathrm{KMO}=0.911 ; \mathrm{Sig} .=0.000)$. Besides, the statements from the scale of the characteristics of the courses $(\mathrm{KMO}=0.626$; $\mathrm{Sig} .=0.000)$ and the scale of benefits $(\mathrm{KMO}=0.672 ; \mathrm{Sig} .=0.000)$ were collected under one factor. The factors attained were used as the dependent and independent variables of the research. To find out the effect of the variables on university satisfaction, the Multiple Linear Regression Analysis were performed by using SPSS 22 packet program.

1 The tables of the reliability analyses of all scales were shown in Appendix I

2 The tables of the exploratory factor analyses of all scales were shown in Appendix II 


\section{Findings and Discussion}

\subsection{Findings}

It was found that $\% 56,3$ of the participants consisted of women while $\% 43,7$ of the participants consisted of men. Besides, $\% 47,8$ of the participants consisted of fresmen while $\% 52,2$ of the participants consisted of seniors. On the other hand, $\% 11,8$ of the participants indicated that their hometown was the city that the university located in while \%88,2 of the participants were found to be from another cities including big cities, cities and rural areas. It was found that $\% 77,9$ of the participants indicated that they prefered the mentioned university because of the fact that their matriculation scores were just adequate for the university while $\% 11,05$ of the participants indicated that they prefered the mentioned university because of their hometown. Besides, it was found that $\% 11,05$ of the participants indicated that they prefered the university for another reasons except from the matriculation score and hometown reasons.

The model indicating that the university satisfaction is dependent variable and the factors attained from factor analysis and the demographical factors are independent variables were tested by using the Multiple Linear Regression Analysis.

Table 3: The Effects of the Independent Variables on University Satisfaction

\begin{tabular}{|c|c|c|c|c|c|c|c|c|c|}
\hline & $\begin{array}{c}\text { Independent } \\
\text { Variables } \\
\end{array}$ & $\begin{array}{l}\text { Std. } \\
\text { Beta }\end{array}$ & $\begin{array}{l}\text { Corre- } \\
\text { lations }\end{array}$ & $\begin{array}{c}\text { Std. } \\
\text { Error }\end{array}$ & $\mathbf{t}$ & $\mathbf{P}$ & $\begin{array}{l}\text { Toler- } \\
\text { ance }\end{array}$ & VIF & Result \\
\hline H1 & Benefits &, 301 & ,748 & ,043 & 6,939 & ,000 & 232 & 4,314 & Accept \\
\hline H2 & \multicolumn{9}{|c|}{ Factors Related to Product } \\
\hline & $\begin{array}{l}\text { Availability/ } \\
\text { Proficiency }\end{array}$ & ,158 & ,003 &, 040 & 4,002 &, 000 & ,279 & 3,582 & Accept \\
\hline & $\begin{array}{c}\text { Communication } \\
\text { Capability }\end{array}$ &, 114 &,- 157 &, 040 & 2,885 & ,004 & ,280 & 3,572 & Accept \\
\hline & $\begin{array}{l}\text { Mentoring } \\
\text { Capability }\end{array}$ & ,103 & ,489 & 035 & 2,965 & ,003 & ,362 & 2,766 & Accept \\
\hline & Helpfullness & 087 &, 169 &, 031 & 2,823 & ,005 & ,460 & 2,176 & Accept \\
\hline & $\begin{array}{c}\text { Course } \\
\text { Characteristics }\end{array}$ & 059 & ,616 & 035 & 1,676 & ,094 &, 351 & 2,850 & Reject \\
\hline H3 & \multicolumn{9}{|c|}{ Factors Unrelated to Products } \\
\hline & $\begin{array}{c}\text { Effeciency of the } \\
\text { Facilities }\end{array}$ &, 012 & ,309 & ,038 & ,328 & ,743 & ,302 & 3,312 & Reject \\
\hline & $\begin{array}{c}\text { Technology } \\
\text { Usage and } \\
\text { Campus }\end{array}$ &, 001 &,- 419 & ,036 &, 034 & ,973 & ,331 & 3,017 & Reject \\
\hline & $\begin{array}{c}\text { Convenience } \\
\text { of Physical } \\
\text { Conditions }\end{array}$ & ,097 & ,064 &, 031 & 3,109 & ,002 & ,448 & 2,230 & Accept \\
\hline
\end{tabular}


Table 3 continued

\begin{tabular}{|c|c|c|c|c|c|c|c|c|c|}
\hline & $\begin{array}{c}\text { Cleaning and } \\
\text { Health Services }\end{array}$ &,- 043 &,- 023 & ,030 & $-1,400$ & ,162 & ,473 & 2,116 & Reject \\
\hline & $\begin{array}{c}\text { University } \\
\text { Image }\end{array}$ & ,036 & , 182 & ,029 & 1,248 & ,002 &, 514 & 1,946 & Accept \\
\hline & $\begin{array}{l}\text { Academic } \\
\text { Success }\end{array}$ &,- 045 &,- 178 & ,039 & $-1,152$ & ,250 & ,283 & 3,537 & Reject \\
\hline $\mathrm{H4}_{\mathrm{a}}$ & Gender/ Male &,- 049 &,- 135 &, 073 & $-1,352$ & ,177 &, 332 & 3,015 & Reject \\
\hline $\mathrm{H4}_{\mathrm{b}}$ & Year of Study &, 018 & ,445 &, 066 &, 534 &, 594 & ,405 & 2,472 & Reject \\
\hline $\mathrm{H4}_{\mathrm{c}}$ & Hometown & ,161 & ,298 &, 196 & 2,537 &, 012 & ,258 & 9,231 & Accept \\
\hline $\mathbf{H} 4_{\mathrm{d} 1}$ & $\begin{array}{l}\text { Reason of } \\
\text { Preference/ } \\
\text { Score } \\
\end{array}$ & ,011 &,- 305 & ,075 & ,357 & ,721 & ,446 & 2,242 & Reject \\
\hline $\mathrm{H} 4_{\mathrm{d} 2}$ & $\begin{array}{l}\text { Reason of } \\
\text { Preference/ } \\
\text { Hometown } \\
\text { Closeness }\end{array}$ &,- 037 & ,285 & ,214 &,- 556 &, 578 & ,296 & 10,366 & Reject \\
\hline \multicolumn{10}{|c|}{$\begin{array}{l}R^{2}=0,839 \\
\text { Adj. } R^{2}=0,830 \\
\text { D-W sta.=2,111 } \\
\text { F sta. }(\text { ANOVA })=101,000[0,000]\end{array}$} \\
\hline
\end{tabular}

Due to the fact that factor scores were used as dependent variables, the standard beta coefficients were used to interpret the results. It was found that the "benefits" variable (standard beta coefficient is 0,301) and availability/proficiency of the academics (standard beta coefficient is 0,158 ) which is a member of factors related to product were the most effective variables on university satisfaction. The other factors related to product and academics' characteristics including communication capability $(\mathrm{p}=0.004 ; \mathrm{p}<0.05)$, mentoring capability $(\mathrm{p}=0.003 ; \mathrm{p}<0.05)$, and helpfullness $(\mathrm{p}=0.005 ; \mathrm{p} \leq 0.05)$ were also found to be effective variables on university satisfaction of the students. Besides, convenience of physical conditions of the university $(\mathrm{p}=0.002 ; \mathrm{p}<0.05)$, and university image $(\mathrm{p}=0.002 ; \mathrm{p}<0.05)$ were also found to be effective variables on university satisfaction of the students. In addition, only the hometown variable $(\mathrm{p}=0.012 ; \mathrm{p}<0.05)$ from the demographical factors was found to be the effective variable on university satisfaction. On the other hand, gender $(\mathrm{p}=0.177 ; \mathrm{p}>0.05)$ and year of study $(\mathrm{p}=0.594 ; \mathrm{p}>0.05)$, score reason $(\mathrm{p}=0.721 ; \mathrm{p}>0.05)$, and hometown reason $(\mathrm{p}=0.578 ; \mathrm{p}>0.05)$ of university preference, efficiency of the facilities $(\mathrm{p}=0.743 ; \mathrm{p}>0.05)$, course characteristics $(\mathrm{p}=0.094 ; \mathrm{p}>0.05)$, technology usage and campus $(\mathrm{p}=0.973 ; \mathrm{p}>0.05)$, cleaning ang health services $(p=0.162 ; p>0.05)$, and academic success $(p=0.250 ; p>0.05)$ of the university were found to have no statistically meaningful effect on university satisfaction of the students.

\subsection{Discussion}

The results of the research indicate that the brand associations provide university satisfaction of the students. The availability/proficiency of academicians which means 
having specialty on his/her field and accessibility by the students when it is needed appears to be a very important variable affecting university satisfaction of students. Besides, the other characteristics of the academicians including communication capability which means effectively communicate with the students, mentoring capability which means guiding the students about future, and helpfullness which means giving practical information to the students also appear to be very important variables affecting university satisfaction of the students. On the other hand, some factors unrelated to product including efficiency of facilities, cleaning and health services, technology usage and campus, and academic success were found as variables having no effect on university satisfaction. Benefits variable which is one of the brand associations was determined to have positive effect on university satisfaction. Besides, only the hometown variable of demographical factors was found to have effect on university satisfaction.

\subsubsection{Managerial Implications}

The regresson analysis results indicate that the most pleasing variables on students mostly consist of academicians' characteristics which is an element of the factors related to product. The academicians' characteristics including availability, proficiency, communication capability, mentoring capability and helpfullness are the variables increasing satisfaction level of the students. In the research, the existing situation of the university was evaluated, thus it can be said that the existing academicians at the faculty of economics and administrative sciences in the subject university have the characteristics increasing satisfaction level of the students. On the other hand, the course characteristics were found to have no effect on university satisfaction. This result is an indicator showing that the characteristics of courses including the method, stimulating factor, and the context should be revised so that the courses can increase the satisfaction level of the students. On the other hand, the university management should increase the effectiveness and number of the facilities including sport center, cafeteria, and library evaluated as inadequate by the students. Besides, the management of the university should improve the cleaning conditions and health services which are very important indicators of physical effectiveness. The university management should concern the opinions of the students about some social activities including spring festival, and should regulate the conditions by basing on the students' opinions. Besides, the attractiveness of the university especially in the eyes of the students whose hometown is not the city where the subject university located in should be improved since the students are the most effective group that will conduct and develop the word of mouth process of the university outside the university location.

\subsubsection{Theoretical Implications}

Research results shows that academicians characteristics were the most effective variables on university satisfaction. This result is compatible with the result found by Yangin and Kirca (2013) showing that academics were effective tools creating satisfaction. Although, Yangin and Kirca (2013) determined that year of study of the students affected university satisfaction, this results showed that year of study was not effective on satisfaction. In addition, this research results indicate that mentoring capability of the academicians was effective on university satisfaction of the students. This result is compatible with the findings of Şahin et al. (2011) indicating that the guidance of the academicians was the most effective variable on university satisfaction of the students. Sökmen (2011) found that gender affected university 
satisfaction of the students, but according to this research, gender has no effect on university satisfaction. To conclude, factors related to product were found to be the most effective variable creating satisfaction of the students towards the university. This result shows the legitimacy of Keller (2000) statement indicating that the factors related to product is very essential so that the product can actualise the performance expected by the customers. So, when the statement is adjusted to this research, it is seen that the academicians within the university are the most effective factors for the students to become satisfied with the university.

\section{Limitations and Future Research}

Due to time limitation, the research was only performed with the students studying at the faculty of economics and administrative sciences in the subject university. Besides, the research was conducted in spring period which might have effect on students perceptions and attitudes. In addition, the experience of the students studied in the other universities which might affect the satisfaction was not measured for this research. To generalise the results, the research should be conducted in other periods as well by involving the students from different faculties and universities. In future researches, adding the city image perception on university satisfaction can contribute to the literature.

\section{References}

Aaker, D. (1996). Building strong brands. New York: The Free Press.

Akar, C. (2012). Üniversite seçimini etkileyen faktörler: İktisadi ve idari bilimler öğrencileri üzerine bir çalışma. Eskişehir Osmangazi Universitesi İIBF Dergisi, 7(1), 97-120.

Akareem, H. S., \& Syed, S. H. (2012). Perception of education quality in private universities of Bangladesh: A study from students' perspective. Journal of Marketing for Higher Education, 1(22).

Alwi, S. F., \& Philip, J. K. (2014). Projecting corporate brand image and behavioral response in business schools: Cognitive or affective brand attributes?. Journal of Business Research, 67, 2324-2336.

Andreassen, T., \& Lindestad, B. (1998). Customer loyalty and complex services. International Journal of Service Industry Management, 9, 7-23.

Baltacı, F., Üngüren, E., Avsallı, H. \& Demirel, O.N. (2012). Turizm eğitimi alan öğrencilerin eğitim memnuniyetlerinin ve geleceğe yönelik bakış açılarının belirlemesine yönelik bir araştırma. International Journal of Alanya Faculty of Business, 4(1), 17-25.

Chen, L. H. (2008). Internationalization or international marketing? Two frameworks for understanding international students' choice of Canadian universities. Journal of Marketing for Higher Education, 1(18), 1-33.

Dinçer, M. K. (2001). İş yaşamında ve özel yaşamda kişisel imaj. İstanbul: Alfa Yayıncılık.

Grönroos, C. (1988). Service quality: The six criteria of good perceived service quality. Review of Business, 3(9), 10-13.

Hunt, S. D. (2010). Marketing theory. New York: M.E. Sharpe. 
İslamoğlu, A. H. \& Altunışık, R. (2013). Tüketici davranışları. İstanbul: Beta Basım.

Jiewanto, A., Laurens, C. \& Nelloh., L. (2012). Influence of service quality, university image, and student satisfaction toward WOM intention: A case study on universitas Pelita Harapan Surabaya. Social and Behavioral Sciences, (40), 16-23.

Kalaycı, E. (2010). SPSS uygulamalı çok değişkenli istatistik teknikleri. Ankara: Asil Yayın Dağıtım.

Karahan, K. (2006). Hizmet pazarlaması. İstanbul: Beta Basım.

Keller, K. L. (2000). Conceptualizing, measuring, and managing customer based brand equity. Journal of Marketing, 1(57), 1-22.

Keller, K. L. (2003). Strategic brand management, building, measuring and managing brand equity. New Jersey: Prentice Hall.

Koç, E. (2012). Tüketici davranışı ve pazarlama stratejileri: Global ve yerel yaklaşım. Ankara: Seçkin Yayıncılık.

Marangoz, M., \& Biber, L. (2007). Kurumsal imajın ve kurumsal ünün müşteri bağlılığına etkileri. Doğus Üniversitesi Dergisi, 2 (8), 173-193.

Owen, F. K., Kepir, D.D., Özdemir, S., Ulaş, Ö. \& Yılmaz, O. (2012). Universite öğrencilerinin bölüm seçme nedenleri. Mersin University Journal of the Faculty of Education, 8 (3), 135-151.

Özdamar, K. (2003). Modern bilimsel araştırma yöntemleri. Eskişehir: Kaan Kitabevi.

Özgüngör, S. (2009). The relationships between students' evaluations of teaching behaviors and self efficacy beliefs. Social and Behavioral Sciences, 1(1), 2687-2691.

Parpala, A., \& Ylanne, S. L. (2007). University teachers' conceptions of good teaching in the units of high-quality education. Studies In Educational Evaluation, 3-4 (33), 355-370.

Pavlina, K., Zorica M. B. \& Pongrac, A. (2011). Student perception of teaching quality in higher education. Social and Behavioral Sciences, (15), 2288-2292.

Perry, A., \& Wisnom, D. (2003). Markanın DNA'sı. (Çev. Z. Yılmaz). İstanbul: MediaCat Yayınları.

Stuart, H. (1999). Towards a definitive model of the corporate identity Management process. Corporate Communications: An International Journal, 4 (4), 200-207.

Sökmen, A. (2011). Öğrenci memnuniyetine yönelik Ankara' daki bir meslek yüksekokulunda araştırma. İsletme Araştırmaları Dergisi, 3 (4), 66-79.

Şahin, A.E. (2009). Eğitim fakültesinde hizmet kalitesinin eğitim fakültesi öğrenci memnuniyet ölçeği (ef-ömö) ile değerlendirilmesi. H. U. Journal of Education, 37, 106-122.

Şahin, İ., Zoraloğlu, Y.R.\& Fırat, N.Ş. (2011). Üniversite öğrencilerinin yaşam amaçları, eğitsel hedefleri, üniversite öğreniminden beklentileri ve memnuniyet durumları. Kuram ve Uygulamada Ĕ̆itim Yönetimi [Educational Administration:Theory and Practice], 17 (3), 429-452.

Tekelioğlu, S., Başer, H., Örtlek, M. \& Aydınlı, C. (2012). Uluslararası öğrencilerin ülke ve üniversite seçiminde etkili faktörler: Vakıf üniversitesi örneği. Organizasyon ve Yönetim Bilimleri Dergisi, 4 (2), 191-200. 
T1ğlı, M. (2003). Kurum imajı kavramı ve sembolik analoji tekniği yoluyla Marmara Üniversitesi'nin kurum imajının belirlenmesine ilişkin bir uygulama. T.C. Marmara Üniversitesi I.I.B.F. Dergisi, 1(18), 245-256.

Torlak, Ö., Doğan, V. \& Özkara, B. Y. (2014). Marka farkındalı̆̆1, marka imajı, markadan etkilenme ve markaya güvenin marka bağlılığı üzerindeki görece etkilerinin incelenmesi: Turkcell örneği. Bilgi Ekonomisi ve Yönetimi Dergisi, 1(9), 147-161.

Wilkins, S., \& Huisman, J. (2014). Corporate images' impact on consumers' product choices: The case of multinational foreign subsidiaries. Journal of Business Research, 67, 22242230.

Yangın, H.B., \& Kırca, N. (2013). Antalya sağlık yüksekokulu hemşirelik öğrencilerinin memnuniyet düzeyleri ve etkileyen faktörler. Gümüşhane University Journal of Health Sciences, 2 (1), 78-94.

Yeygel, S., \& Temel, A. (2006). İşletmelerin kurumsal imajlarının hedef kitlelere iletilmesinde bir araç olarak kurum web siteleri. Ulusal Halkla İlişkiler Sempozyumu, 27-28 Nisan, Kocaeli.

\section{APPENDIX I}

Table I: Reliability Analysis for Academic Staffs' Characteristics Scale (After Omitting Item 2, Item 8, Item 19, Item 22, Item 23, and Item 26 From the Scale)

\begin{tabular}{lc}
\hline Cronbach Alpha Coefficient & 0,913 \\
\hline
\end{tabular}

Items

Cronbach's

Alpha If Items

Deleted

1. He/She gives responsibility to the students.

0,908

2. He/She creates interactive platform during the course.

3. He/She gives the course by associating with the reallife.

0,913

4. He/She gives chance to the students so that they can do brainstorming during the course.

5. He/She gives practical information to the students. $\quad 0,908$

$\begin{array}{ll}6 . \mathrm{He} / \mathrm{She} \text { is an inspiration to the students. } & 0,910\end{array}$

\begin{tabular}{ll}
\hline 7. He/She uses different methodsto teach the students. & 0,908
\end{tabular}

8. He/She is a specialist in his/her department.

$\begin{array}{lr}\text { 9. He/She behaves equally to the students. } & 0,907\end{array}$

10. He/She has sufficient knowledge about the course main theme. 0,908

11. He/She responses the questions of the students in a specialistic way. $\quad 0,910$

12. He/She clearly defines the objectives of the courses. 0,906

13. He/She is good at communicating with the students. $\quad 0,912$

$\begin{array}{ll}14 . \mathrm{He} / \mathrm{She} \text { shows respect to the students. } & 0,904\end{array}$

$\begin{array}{lr}15 . \mathrm{He} / \mathrm{She} \text { is punctual. } & 0,912\end{array}$

16. He/She gives information about his(her adademic background. $\quad 0,912$ 


\section{Table I continued}

$\begin{array}{lr}\text { 17. He/She is academically well-qualified. } & 0,909\end{array}$

$\begin{array}{lr}\text { 18. He/She effectively presents the course. } & 0,907\end{array}$

19. He/She is responsive in giving mark.

20. He/She is sensitive to the daily events. 0,913

21. He/She shares his/her philosophy. 0,913

22. He/She imposes on his/her philosophy.

23. He/She gives information about daily events.

24. He/She gives eye-opening information to the students. 0,905

25. He/She motives students about future. $\quad 0,913$

26. He/She pays attention to his/her appearances.

27. I can easily communicate with the academic when I need. 0,911

28. I feel free to ask question to the academic when I do not understand. $\quad 0,908$

29. I know that the academic welcome me and show me tolerance when $\quad 0,912$

I make a mistake.

Table II: Reliability Analysis for Physical Conditions of the University Scale (After Omitting Item 1 and Item 13 From the Scale)

\section{Cronbach Alpha Coefficient}

Items
0,770

Cronbach's

Alpha If Items

Deleted

1. The classrooms are crowded.

2 . The faculty building and the other physical places (toilet, canteen, etc...) are sufficient.

3. The classrooms are well qualified for teaching.

0,733

4. The modern equipment are used during the class.

0,767

5 . The campus place is sufficient.

0,770

6. The illumination is sufficiently made in the campus at nights.

0,762

7. The library of the university is sufficient.

0,763

8 . The gymnasium of the university is sufficient.

0,739

9. The security services of the university is sufficient.

0,722

10. The university includes an infirmary that gives services in time that is needed.

0,741

11. The university includes a psychological counseling and guidance room fort he students.

0,757

12. The cleaning services are regularly being pursued in the university.

0,753

13. The campus is close to the important centers (such as hospital, shopping centers, ATM, etc...). 
Table III: Reliability Analysis for The Courses' Characteristics of the University Scale

\begin{tabular}{|c|c|}
\hline Cronbach Alpha Coefficient & $\mathbf{0 , 7 5 4}$ \\
\hline Items & $\begin{array}{c}\text { Cronbach's } \\
\text { Alpha If Items } \\
\text { Deleted }\end{array}$ \\
\hline 1. The courses are well-structured. & 0,609 \\
\hline 2. The course brings a point of view on basic problems to the students. & 0,751 \\
\hline $\begin{array}{l}\text { 3. The course provides opportunity for the students to make } \\
\text { implementations. }\end{array}$ & 0,705 \\
\hline $\begin{array}{l}\text { 4. The number of subjects within the context of the course is compatible } \\
\text { with the course hours. }\end{array}$ & 0,753 \\
\hline $\begin{array}{l}\text { 5. The course literature is beneficial in terms of intelligibility of the main } \\
\text { subject. }\end{array}$ & 0,704 \\
\hline
\end{tabular}

Table IV : Reliability Analysis for The Institutional Characteristics of the University Scale (After Omitting Item 2,6,7,10,12,13,16,21,22,33)

\begin{tabular}{lc}
\hline Cronbach Alpha Coefficient & $\mathbf{0 , 9 5 0}$ \\
\hline Items & Cronbach's \\
Alpha If Items
\end{tabular}

1. The ranking of the university across Turkey is good. $\quad 0,948$

2. The ranking of the department that I study on across Turkey is good.
3. The university environment is compatible with the academic environment.

4. The university pursues activities stimulating success of the students (such as giving scholarship, giving award, etc...).

5 . The web site of the university is user-friendly.

6. I do not feel difficulty in course taking.

7. I have difficulty in using e-campus.

8. I can easily access the advisors in course taking week.

0,948

9. I trust the academic staffs of the university.

0,948

10. The university management informs the students' parents about the students' condition.

11. I feel free to share my problems with the university management.

0,947

12. There are social responsibility projects being pursued within the university.

13. There are academic conferences being held within the university.

14. The student clubs actively work within the university. $\quad 0,950$

$\begin{array}{ll}15 \text {. The university image associates with the city image. } & 0,950\end{array}$ 


\section{Table IV continued}

16. The university has an apparent logo.

17. The logo of the university associates with the university image. $\quad 0,949$

18. The university has an apparent motto. $\quad 0,949$

19. The motto of the university is compatible with the university image. $\quad 0,950$

20. The geographical position of the university is charming. $\quad 0,947$

21 . The university has green places.

22. The university facilitaties students to attend social activities such as sport teams, folk dances, theatre, etc...

23. I am pleased with the spring festivals of the university.

0,948

24. I am pleased that I study in this university.

0,946

25. I am pleased with my department that I study on.

0,947

26. I recommend this university to my friends.

0,947

27. I am pleased that I live in this city.

0,947

28. I encourage people around me tol ive in this city.

0,947

29. Before I start studying in this university, my feelings about the university were positive.

0,949

30. After I started studying in this university, my feelings about the university changed positively.

0,946

31. Before I came to this city, my feelings about the city were positive.

0,950

32. After I had come to this city, my feelings about the city changed positively.

33. My feelings about this city affect my feelings about the university.

34. This university was among the first five university that I wanted to study in.

0,947

Table V: Reliability Analysis for Benefits Scale

\section{Cronbach Alpha Coefficient}

$\mathbf{0 , 7 7 0}$

Cronbach's

Items

Alpha If Items

Deleted

1. I have nice memories about my university.

0,688

2. I get pleasure by watching news about my university.

0,601

3. Talking about my university temporarily makes me forget my problems.

4. I like the social environment within the university.

0,750 


\section{APPENDIX II}

Table VI: Academic Staff's Characteristics Scale Exploratory Factor Analysis

\begin{tabular}{|c|c|c|c|c|}
\hline & Factor Weight & Initial Eigenvalue & Variance & $\alpha$ \\
\hline \multicolumn{5}{|c|}{ Factor 1: Proficiency/Availability } \\
\hline Item 9 & 0,675 & & & \\
\hline Item 10 & 0,794 & & & \\
\hline Item 11 & 0,814 & & & \\
\hline Item 14 & 0,765 & 8,266 & 35,940 & 0,886 \\
\hline Item 21 & 0,690 & & & \\
\hline Item 27 & 0,809 & & & \\
\hline Item 28 & 0,532 & & & \\
\hline
\end{tabular}

Factor 2: Mentoring Capability

\begin{tabular}{lllll}
\hline Item 5 & 0,630 & & & \\
\hline Item 6 & 0,587 & & & \\
\hline Item 7 & 0,668 & & 11,522 & 0,867 \\
\hline Item 12 & 0,770 & 2,650 & & \\
\hline Item 16 & 0,655 & & \\
\hline Item 24 & 0,723 & & \\
\hline Item 29 & 0,624 & &
\end{tabular}

Factor 3: Communication Capability

\begin{tabular}{lllll}
\hline Item 13 & 0,767 & & & \\
\cline { 1 - 1 } Item 15 & 0,824 & 2,239 & 9,736 & 0,788 \\
\hline Item 18 & 0,616 & & & \\
\hline Item 20 & 0,654 & & & \\
\hline
\end{tabular}

Factor 4: Helpfullness

\begin{tabular}{lllll}
\hline Item 4 & 0,762 & & & \\
\hline Item 6 & 0,635 & 1,476 & 6,417 & 0,743 \\
\hline Item 25 & 0,810 & & & \\
\hline
\end{tabular}

KMO $=0,852$, Barlett's Test of Sphericity $\mathbf{p}=.000$, Total Explained Variance $=\% 62,690$ 
Table VII: Physical Conditions of the University Scale Exploratory Factor Analysis

\begin{tabular}{|c|c|c|c|c|}
\hline & Factor Weight & Initial Eigenvalue & Variance & $\alpha$ \\
\hline \multicolumn{5}{|c|}{ Factor 1: Efficiency of Facilities } \\
\hline Item 2 & 0,686 & \multirow{5}{*}{3,469} & \multirow{5}{*}{31,535} & \multirow{5}{*}{0,803} \\
\hline Item 7 & 0,548 & & & \\
\hline Item 8 & 0,858 & & & \\
\hline Item 9 & 0,698 & & & \\
\hline Item 11 & 0,737 & & & \\
\hline \multicolumn{5}{|c|}{ Factor 2: Technology Usage and Campus } \\
\hline Item 4 & 0,854 & \multirow{2}{*}{2,107} & \multirow{2}{*}{19,156} & \multirow{2}{*}{0,696} \\
\hline Item 5 & 0,839 & & & \\
\hline \multicolumn{5}{|c|}{ Factor 3: Convenience of Physical Conditions } \\
\hline Item 3 & 0,729 & \multirow{3}{*}{1,367} & \multirow{3}{*}{12,423} & \multirow{3}{*}{0,618} \\
\hline Item 6 & 0,724 & & & \\
\hline Item 7 & 0,674 & & & \\
\hline \multicolumn{5}{|c|}{ Factor 4: Cleaning and Health Services } \\
\hline Item 10 & 0,538 & \multirow{2}{*}{1,069} & \multirow{2}{*}{9,716} & \multirow{2}{*}{0,503} \\
\hline Item 12 & 0,866 & & & \\
\hline
\end{tabular}

KMO $=0,657$, Barlett's Test of Sphericity $\mathbf{p}=.000$, Total Explained Variance $=\% 72,830$

Table VIII: The Courses' Characteristcis of the University Scale Exploratory Factor Analysis

$$
\text { Factor Weight Initial Eigenvalue Variance } \alpha
$$

Factor 1: The Courses Characteristics

\begin{tabular}{|c|c|c|c|c|}
\hline Item 1 & 0,898 & \multirow{5}{*}{2,622} & \multirow{5}{*}{52,444} & \multirow{5}{*}{0,754} \\
\hline Item 2 & 0,618 & & & \\
\hline Item 3 & 0,756 & & & \\
\hline Item 4 & 0,538 & & & \\
\hline Item 5 & 0,756 & & & \\
\hline
\end{tabular}

KMO=0,626, Barlett's Test of Sphericity p=.000, Total Explained Variance $=\% 52,444$ 
Table IX: The Institutional Characteristics of the University Scale Exploratory Factor Analysis

\begin{tabular}{|c|c|c|c|c|}
\hline & Factor Weight & Initial Eigenvalue & Variance & $\alpha$ \\
\hline \multicolumn{5}{|c|}{ Factor 1: University Satisfaction } \\
\hline Item 8 & 0,639 & & & \\
\hline Item 9 & 0,530 & & & \\
\hline Item 11 & 0,691 & & & \\
\hline Item 20 & 0,746 & & & \\
\hline Item 23 & 0,654 & & & \\
\hline Item 24 & 0,839 & & & \\
\hline Item 25 & 0,776 & 11,532 & 48,050 & 0,956 \\
\hline Item 26 & 0,846 & & & \\
\hline Item 27 & 0,828 & & & \\
\hline Item 28 & 0,850 & & & \\
\hline Item 30 & 0,775 & & & \\
\hline Item 32 & 0,848 & & & \\
\hline Item 34 & 0,720 & & & \\
\hline
\end{tabular}

Factor 2: Academic Success

\begin{tabular}{lllll}
\hline Item 1 & 0,650 & & & \\
\cline { 1 - 2 } Item 3 & 0,795 & 2,204 & 9,181 & 0,824 \\
\hline Item 4 & 0,603 & & \\
\hline Item 14 & 0,789 & & \\
\hline
\end{tabular}

Factor 3: University Image

\begin{tabular}{lllll}
\hline Item 15 & 0,712 & & \\
\hline Item 17 & 0,665 & 1,836 & 7,650 & 0,780 \\
\hline Item 18 & 0,750 & & & \\
\hline Item 19 & 0,746 & &
\end{tabular}

KMO $=0,911$, Barlett's Test of Sphericity p $=.000$, Total Explained Variance $=\% 64,873$

Table X: Benefits Scale Exploratory Factor Analysis

\begin{tabular}{llccc}
\hline & Factor Weight & Initial Eigenvalue & Variance & $\boldsymbol{\alpha}$ \\
\hline \multicolumn{1}{l}{ Factor 1: Benefits } & & & & \\
\cline { 1 - 2 } Item 1 & 0,803 & & & \\
\cline { 1 - 2 } Item 2 & 0,916 & 2,410 & 60,254 & 0,770 \\
\cline { 1 - 2 } Item 3 & 0,892 & & & \\
\hline Item 4 & 0,502 & & & \\
\hline
\end{tabular}

KMO $=0,672$, Barlett's Test of Sphericity $\mathbf{p}=.000$, Total Explained Variance $=\% 60,254$ 